\title{
Factors Affecting Productivity of Technical Personnel in Turkish Construction Industry: A Field Study
}

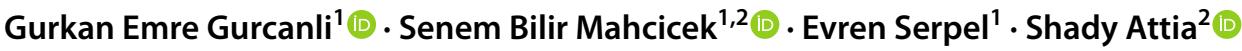

Received: 21 February 2021 / Accepted: 29 May 2021

(c) King Fahd University of Petroleum \& Minerals 2021

\begin{abstract}
The construction industry has great importance for the economy, especially in developing countries. While having such great importance at macro level, there are many uncertainties for the industry to overcome. Productivity is one of the most important uncertainties in the industry. Most of the companies in the industry do not have any performance measure or efficient criteria for the technical personnel, and the work outcomes of the technical personnel are not quantifiable. This study aims to identify and rank the multi-causal factors affecting the productivity of technical personnel in the construction industry. For this purpose, a detailed questionnaire survey was taken among 400 professionals in the construction industry. Kaiser-Meyer-Olkin measure of sampling adequacy, Barlett's test of sphericity which makes Cronbach's alpha, and reliability tests were conducted on the results of the questionnaire survey. The relative importance index was used for ranking the importance level of the factors. The top nine factors affecting technical personnel's productivity are listed as Management, External and Owner Related, Motivational, Financial, Working Condition, Welfare and Comfort, Lacking Resources, Personal and Workload factors in the study, and $47 \%$ of these factors affecting technical personnel's' productivity are expressed by management factors. The most important factor groups after the management factors are working conditions, human factors and external factors, respectively. It is thought that the results of this research will shed light on for further research that focus on maximizing the productivity of technical personnel in the construction industry.
\end{abstract}

Keywords Relative importance index $\cdot$ Factor analysis $\cdot$ Multi-casual factors $\cdot$ Cluster analysis

\section{Introduction}

The construction industry has a significant role in the development of an economy; there are mutual and causal relationships between the industry and gross domestic product (GDP) $[1,2]$. Despite a slight slowdown, the construction

Senem Bilir Mahcicek

sbilir@itu.edu.tr

Gurkan Emre Gurcanli

gurcanlig@itu.edu.tr

Evren Serpel

eserpel@itu.edu.tr

Shady Attia

shady.attia@uliege.be

1 Division of Construction Management, Civil Engineering Department, Istanbul Technical University, Ayazaga Campus, Maslak, 34469 Istanbul, Turkey

2 SBD Lab, Department UEE, Faculty of Applied Sciences, Université de Liège, Liege, Belgium industry continues to grow at a slow pace. The long-term attitude of the global construction industry is positive, and the industry is thought to expand above the global gross domestic product (GDP) growth in the next era. Factors that will affect the growth of construction industry include population increases (in developing countries), necessary improvements in infrastructure (in developed countries), increased housing development trend, renewable energy and telecommunications investments [3].

During the last few decades, Turkish contracting firms have been expanding globally. Accordingly, the demand for technical personnel in the industry is expanding as well. Technical personnel can be defined as the personnel who works between the field workers and management office such as architects, site engineers, site safety experts, electricians and supervisors. The construction industry's contribution to GDP at current prices is nearly $5 \%$, and the share of the industry in total employment is about $7 \%$. According to Turkish Contractors Association (2016) [4], the construction industry's contribution to the Turkish Economy reaches 
up to $30 \%$ and the employment rate (excluding agriculture) reaches up to $10 \%$, if the direct and indirect impacts on other sectors are taken into account.

While having such a great importance at macro level, there are many uncertainties for the industry to overcome $[5,6]$. Contingencies that exist in the construction industry make this sector risky in terms of project management, because the outer parameters affect the project management as much as the inner parameters like health and safety measures taken on the construction site [7]. Productivity is one of the most important uncertainties of the industry. Construction is a labor-intensive industry, and the efficiency of a construction project mostly depends on the productivity of the employees. Therefore, the productivity of labor in the construction industry has become one of the most researched topics $[8,9]$. However, the productivity of technical staff (i.e., architects, and site engineers) has not been investigated yet.

The objective of this research is the identification and ranking of multi-causal factors that affect productivity of technical staff in the construction industry. Thus, the outcomes can be used by not only Turkish contractors, but also international construction firms who may be interested in working with Turkish contractors on large-scale projects in order to have a solid idea about factors affecting productivity and help project managers increase the performance of technical personnel and the competitiveness of the firm.

\section{Literature Review}

The word "productivity" was first used in the 1700s by Quesnay in an article [8]. According to the available data and used parameters, numerous definitions of productivity can be found in the literature. According to the Bureau of Labour Statistics (2013) of U.S. Department of Labour, the definition of productivity is "a measure of economic efficiency which shows how effectively economic inputs are converted into output" [10], whereas Arditi and Mochtar (2000) stated that productivity is "the ratio between total outputs expressed in Dollars and total inputs expressed in Dollars as well" [11]. Vogl and Abdel-Wahab (2015) described productivity as a measure of effectiveness with which the economy runs inputs such as workforce and money into output [2]. Moreover, Horner et al. (1989) defined productivity as the ratio of earned to actual hours [12]. Allmon et al. (2000) stated that productivity is relative measure of labor efficiency, whether positive or negative, once compared to a proven base or standard [13]. Durdyev et al. (2018) stated that all definitions of productivity have a relation with efficiency and effectiveness regardless of the study objectives, resources and benchmarks used, and measures accepted [14]. Subsequently, productivity is defined as a ratio of a volume measure of output, to a volume measure of input in general [1].

There has been a quite extensive amount of studies related to productivity in the construction industry [15-23]. The factors affecting construction productivity have been a matter of debate for a long time and the factors, either good or bad, are essential to increasing productivity of construction projects. In the literature, some of the scientists focused on investigation of the factors impacting only construction laborers' productivity, whereas the others analyzed all components of construction projects to find out the most critical factors of productivity. For instance, Dai et al. (2009b) surveyed the causes of the factors that affect the craft workers' productivity in construction projects [24]. They found construction equipment, materials, tools and consumables, engineering drawing management, direction and coordination, project management, training, craft worker qualifications, superintendent competency, and foreman competency as the latent productivity factors for craft workers in the USA. Kisi et al. (2017) presented a two-prong strategy for calculating optimal productivity of labor-intensive constructions in a pilot study and as a result, they shared a framework to calculate the optimal productivity for labor-intensive construction works [25]. Goodrum et al. (2009) investigated the correlation between material technology and construction productivity by using labor and factor productivity measures [15]. However, none of them have worked on the factors that exclusively influence the construction technical personnel. In this research, more than 60 papers in relation to construction productivity were reviewed and only 11 of the most relevant and key publications were listed in Table 1.

According to the extensive literature review, no research could be found that directly focused on the productivity of technical personnel. This paper is designed to fill the gap in the literature, addressing the factors that specify the productivity of construction industry professionals, not only for Turkish constructors but also for any international contractors which may need to work with Turkish contractors.

\section{Methodology}

This study followed a mixed method research approach combining qualitative and quantitative methods as shown in Fig. 1. The factors affecting productivity of the construction technical personnel are investigated based on a literature review-based questionnaire. To define the productivity factors, 10 industry professionals were asked about the influence of factors, which were collected from literature, via semi-structured face-to-face interviews. Finally, 60 productivity factors were determined for Turkey. Then, a qualitative approach was used to create a structured, close-ended questionnaire. The empirical approach of the study collected 
Table 1 A brief literature review about the factors influencing construction productivity

\begin{tabular}{|c|c|c|c|}
\hline Reference & \# of factors & Gap & Most influencing factors on productivity \\
\hline Kaming et al. (1997) [26] & 16 & $\begin{array}{l}\text { It was conducted only for craft workers, not } \\
\text { for tech. personnel }\end{array}$ & $\begin{array}{l}\text { lack of materials; rework; absenteeism; lack } \\
\text { of equipment; and tools }\end{array}$ \\
\hline Horner et al. (1989) [12] & 13 & $\begin{array}{l}\text { It was conducted only for labors, not for } \\
\text { tech personnel }\end{array}$ & $\begin{array}{l}\text { skill of labor, buildability quality of supervi- } \\
\text { sion, method of working, incentive scheme, } \\
\text { site layout, complexity of construction } \\
\text { information and so on }\end{array}$ \\
\hline Lim \& Alum (1995) [27] & 17 & $\begin{array}{l}\text { The study is too comprehensive; it does not } \\
\text { focus on tech personnel }\end{array}$ & $\begin{array}{l}\text { lack of qualified supervisors, shortage of } \\
\text { skilled labor, high rate of labor turnover, } \\
\text { labor absenteeism, and communications } \\
\text { with foreign laborers }\end{array}$ \\
\hline Thomas et al. (1990) [28] & 15 ( 2 main categories) & $\begin{array}{l}\text { It was conducted only for labors, not for } \\
\text { tech personnel }\end{array}$ & $\begin{array}{l}\text { job skills, quality of management, availabil- } \\
\text { ity of resources, and the degree of difficulty } \\
\text { and complexity of the work }\end{array}$ \\
\hline Heale (1993) [29] & 28 (3 main categories) & $\begin{array}{l}\text { The study is too comprehensive, it does not } \\
\text { focus on tech personnel }\end{array}$ & $\begin{array}{l}\text { availability/clarity of working drawings, non- } \\
\text { availability of tools, equipment breakdown, } \\
\text { inappropriate use of labor }\end{array}$ \\
\hline Kazaz et al. (2008) [30] & 37 ( 4 main categories) & $\begin{array}{l}\text { It was conducted only for labors, not for } \\
\text { tech personnel }\end{array}$ & $\begin{array}{l}\text { Quality of site management, on-time pay- } \\
\text { ment, material management }\end{array}$ \\
\hline Liberda et al. (2003) [31] & 49 (3 main categories) & $\begin{array}{l}\text { The study is too comprehensive, it does not } \\
\text { focus on tech personnel }\end{array}$ & $\begin{array}{l}\text { Lack of detailed planning, worker experience } \\
\text { and skills, inadequate supervision, worker } \\
\text { motivation, non-availability of materials }\end{array}$ \\
\hline Jarkas and Bitar (2011) [8] & 45 (4 main categories) & $\begin{array}{l}\text { It was conducted only for labors, not for } \\
\text { tech personnel }\end{array}$ & $\begin{array}{l}\text { Clarity of technical specifications, the extend } \\
\text { of variation, coordination level among } \\
\text { design disciplines }\end{array}$ \\
\hline Mahamid (2013) [32] & 31 & $\begin{array}{l}\text { It was conducted only for labors, not for } \\
\text { tech personnel }\end{array}$ & $\begin{array}{l}\text { Rework, lack of cooperation, lack of commu- } \\
\text { nication between construction parties, lack } \\
\text { of materials and labor experience, financial } \\
\text { status of the owner }\end{array}$ \\
\hline Enshassi et al. (2007) [1] & 45 & $\begin{array}{l}\text { It was conducted only for labors, not for } \\
\text { tech personnel }\end{array}$ & $\begin{array}{l}\text { Lack of labor experience and surveillance, } \\
\text { materials storage, drawing and specifica- } \\
\text { tions alteration }\end{array}$ \\
\hline Dai et al. (2009a) [33] & 83 & $\begin{array}{l}\text { It was conducted only for craft workers, not } \\
\text { for tech personnel }\end{array}$ & $\begin{array}{l}\text { Wages, tools, consumables, materials, } \\
\text { engineering drawing management and } \\
\text { construction equipments }\end{array}$ \\
\hline
\end{tabular}

the data from 400 professionals and used nonparametric statistical techniques for data analysis.

The obtained data was analyzed by utilizing three differ-

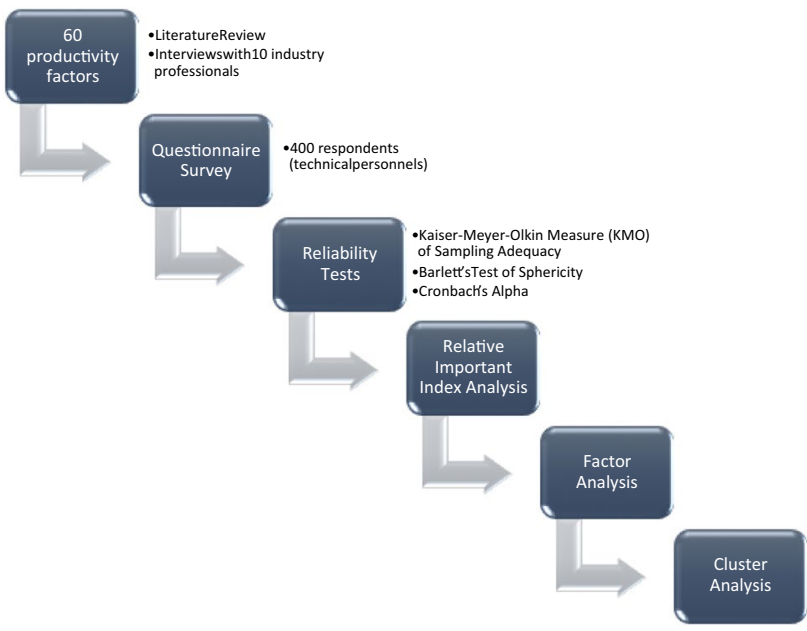

Fig. 1 Study conceptual framework ent statistical methods, namely: relative importance index (RII), factor analysis and cluster analysis. The RII was calculated via MS Excel while the factor analysis and cluster analysis were conducted via the Statistical Package for Social Science (SPSS) software [34].

\subsection{Data Collection}

The aim of this questionnaire survey was twofold: (1) to define the most critical factors that affect technical personnel in the construction industry; and (2) to investigate the relationship between those factors. The target population of this questionnaire was Turkish technical personnel which are project managers, architects, site supervisors, site engineers, safety experts and other technical personnel and the only criterion for the respondents was to work in the construction 
industry as technical personnel. The questionnaire was distributed to 494 industry professionals via an online form and more than 400 respondents completed the questionnaire, but only 400 precisely filled out responses were used for analyses in this research. The Likert type scale was used for ranking the factors affecting technical personnel in the construction industry. Weisberg (2005) stated that the usage of a middle scale answer might affect the answer of the respondents by 10 to $20 \%$ or even more [35]. Hence, the questions were designed to be 6 Likert scaled and were gradually rated from 0 to 5 as 0 equals to none and 5 means very good.

The questionnaire was formed under three sections: in the first section, the aim of the research was explained to the respondent; in the second section, demographic information of the respondent was asked with ten specific questions; and in the third section, participants were asked their perception with regard to factors affecting technical personnel in the construction industry. The factors were grouped under 4 major categories: (1) Human, (2) Management, (3) External, and (4) Working Conditions. The factors under these categories were identified through a literature review and expert opinions, and all factors were listed as seen in Tables 2, 3, 4 , and 5 with their references.

\subsection{Reliability Tests}

For the trustworthiness of the collected data, 3 different kinds of reliability tests have been conducted. As it is explained in the below, subsections all of the three reliability tests resulted in satisfying outcomes which proved the dependability of the dataset.

\subsubsection{Kaiser-Meyer-Olkin Measure (KMO) of Sampling Adequacy}

The KMO score of the dataset was found out that it falls into marvelous category with a score of 0.911 . The KMO score of the dataset was not only acceptable but also in the best possible category for the analysis.

\subsubsection{Barlett's Test of Sphericity}

The significance level of dataset is 0 which shows that the dataset is meaningful. The approximate Chi-Square value was found at 8142.342 and the df value was calculated as 946.

\subsubsection{Cronbach's Alpha}

The Cronbach's alpha value, which shows the internal consistency level of the dataset, is 0.948 . This value shows that by being over 0.9 our dataset is excellent with regard to internal consistency. The Cronbach's alpha was measured for each of the 60 factors; however, as a result of the reliability test, it has been observed that "Personnel's gender" factor is not meaningful for the dataset. "Personnel's gender" factor has quite a low Corrected Item-Total Correlation value (0.027) than other factors. Additionally, "Personnel's gender" factor was not included in the similar previous studies in construction industry. Therefore, it was removed from the determined factors before conducting factor analysis.

Table 2 Human factors

\begin{tabular}{lll}
\hline Category & Factor description & Resource \\
\hline Human factors & Personnel's motivation & Liberda et al. (2003) [31] \\
Human factors & Team spirit of the crew & Liberda et al. (2003) [31] \\
Human factors & Personnel's experience and skills & Liberda et al. (2003) [31] \\
Human factors & Personnel's attitude and morale & Liberda et al. (2003) [31] \\
Human factors & Personnel's boredom and fatigue & Liberda et al. (2003) [31] \\
Human factors & Personnel's job satisfaction & Kazaz et al. (2008) [31] \\
Human factors & Loyalty to job & Various resources \\
Human factors & Perception/misperception & Various resources \\
Human factors & Personnel's learning curve & Liberda et al. (2003) [31] \\
Human factors & Personnel's absenteeism & Liberda et al. (2003) [31] \\
Human factors & Loyalty to company & Various resources \\
Human factors & Personnel's physical limitations & Liberda et al. (2003) [31] \\
Human factors & Personnel's age & Robbins and Judge (2003) [36], Rowold and Heinitz (2007) [37] \\
Human factors & Personnel's marital status & Robbins and Judge (2003) [36], Rowold and Heinitz (2007) [37] \\
Human factors & Personnel's gender & Robbins and Judge (2003) [36], Rowold and Heinitz (2007) [37] \\
\hline
\end{tabular}


Table 3 Management factors

\begin{tabular}{|c|c|c|}
\hline Category & Factor description & Resource \\
\hline Management factors & Inadequate supervision & Liberda et al. (2003) [31] \\
\hline Management factors & Inadequate communication & Liberda et al. (2003) [31] \\
\hline Management factors & Salary and benefits & Liberda et al. (2003) [31] \\
\hline Management factors & $\begin{array}{l}\text { Lack of clear organization chart and SOW } \\
\text { (Scope of Work) }\end{array}$ & Various resources \\
\hline Management factors & Delay in salary payment & Enhassi et al. (2007) [1] \\
\hline Management factors & Lack of detailed planning & Liberda et al. (2003) [31] \\
\hline Management factors & Non-availability of information & Liberda et al. (2003) [31] \\
\hline Management factors & Lack of recognition program & Jarkas and Bitar (2011) [8] \\
\hline Management factors & Discontinuity in crew & Liberda et al. (2003) [31] \\
\hline Management factors & Lack of cooperation between departments & Liberda et al. (2003) [31] \\
\hline Management factors & Necessity to re-do work & Liberda et al. (2003) [31] \\
\hline Management factors & Composition of the teams & Liberda et al. (2003) [31] \\
\hline Management factors & Excessive workload & Heale (1993) [29] \\
\hline Management factors & Incompetent personnel & Liberda et al. (2003) [31] \\
\hline Management factors & Unrealistic schedule & Liberda et al. (2003) [31] \\
\hline Management factors & Non-availability of equipment & Liberda et al. (2003) [31] \\
\hline Management factors & Non-availability of materials/softwares & Liberda et al. (2003) [31] \\
\hline Management factors & Interruption and disruption & Liberda et al. (2003) [31] \\
\hline Management factors & End of project effect & Heale (1993) [29] \\
\hline Management factors & Out-of-sequence work & Liberda et al. (2003) [31] \\
\hline Management factors & Failure to utilize personnel's skills & Liberda et al. (2003) [31] \\
\hline Management factors & Lack of procedures & Liberda et al. (2003) [31] \\
\hline Management factors & Lack of personnel training and education & Liberda et al. (2003) [31] \\
\hline Management factors & Proportion of work subcontracted & Jarkas and Bitar (2011) [8] \\
\hline Management factors & Lack of workload & Various resources \\
\hline
\end{tabular}

Table 4 External factors

\begin{tabular}{lll}
\hline Category & Factor description & Resource \\
\hline External factors & $\begin{array}{l}\text { Accidents at site as a result of poor site safety } \\
\text { program } \\
\text { Owner's representative intervention }\end{array}$ & Jarkas and Bitar (2011) [8] \\
External factors & Demand of over-quality work & Jarkas and Bitar (2011) [8] \\
External factors & Changes in drawings and specifications & Liberda et al. (2003) [31] \\
External factors & Method of construction & Liberda et al. (2003) [31] \\
External factors & Changes in contract & Jarkas and Bitar (2011) [8] \\
External factors & Nature of project (size and complexity) & Liberda et al. (2003) [31] \\
External factors & Weather conditions/climate & Liberda et al. (2003) [31] \\
External factors & Congested construction area & Liberda et al. (2003) [31] \\
External factors & Union rules and influences & Liberda et al. (2003) [31] \\
External factors & & Liberda et al. (2003) [31] \\
\hline
\end{tabular}

\subsection{Data Analysis}

\subsubsection{Relative Important Index (RII)}

For defining factors affecting productivity in the construction industry, numerous studies have been carried out using the RII in order to rank the factors as per the results of the questionnaire survey $[1,20,22,30,38,39]$. Simply, RII is a tool to rank the factors in accordance with the answers given by the respondents who complete the questionnaire survey. In this research, to calculate the relative importance of the factors, the formula given in Eq. 1 was used in this study.

$$
\operatorname{RII}(\%)=\frac{5(n 5)+4(n 4)+3(n 3)+2(n 2)+1(n 1)+0(n 0)}{5(n 1+n 2+n 3+n 4+n 5+n 0)} \times 100 .
$$


Table 5 Working conditions factors

\begin{tabular}{lll}
\hline Category & Factor description & Resource \\
\hline Working conditions & Disrespectful treatment (mobbing) & Liberda et al. (2003) [31] \\
Working conditions & Excessive shift length & Liberda et al. (2003) [31] \\
Working conditions & Unsafe working conditions & Liberda et al. (2003) [31] \\
Working conditions & Unpaid overtime & Liberda et al. (2003) [31] \\
Working conditions & Transportation to work & Jarkas and Bitar (2011) [8] \\
Working conditions & Noise, dust and radiation & Liberda et al. (2003) [31] \\
Working conditions & Ventilation system (heating \& air condition- & Enhassi et al. (2007) [1] \\
& ing) & \\
Working conditions & Cleanliness of working space & Liberda et al. (2003) [31] \\
Working conditions & Overcrowded work areas & Liberda et al. (2003) [31] \\
Working conditions & Parking facilities & Liberda et al. (2003) [31] \\
\hline
\end{tabular}

In the formula shown in Eq. $1, n 5$ to $n 0$ refers to the number of respondents who responded to the related factor with a score of 0 to 5 in which 0 refers to not rated and 5 is very high. However, $\mathrm{n} 0$ has no impact on the numerator, since it increases the denominator and it affects the RII of the factor. The score for each factor multiplied number of respondents for each score from 0 to 5 . Then, it is divided by the highest rating, which is a multiplication of 5 with the total number of respondents. The result of this calculation is multiplied with one hundred in order convert it to an index over one hundred as a percentage. In Table 6, all factors are listed in accordance with RII.

Factors that have a RII score over $80 \%$ with the mean over 4 show that participants ranked them between high to very high. Seventeen factors have a RII score over $80 \%$ with the mean over 4 , and can be considered as the most important factors affecting the productivity of technical personnel in construction sites. Among these 17 factors, there are 7 management, 6 human and 4 working conditions-related factors. On the other hand, 8 factors have a RII score under $60 \%$ with the mean less than 3, which are assumed to have low effect on productivity of technical personnel. Among these 8 factors, there are 3 "human," 2 "management," 2 "external" and 1 factor related with "working conditions."

The "Personnel's motivation" factor ranked in the first place with the mean as 4.33 . It can be presumed that motivation is very important, driving factor. Motivation can be described as a trigger for humans which defines the direction of their acts, thoughts, hopes, beliefs, in short desires, needs and insecurities [40]. Technical personnel can be motivated by adding motivational factors such as responsibility in tasks, assignment to higher-level tasks, personal growth and rewards. For instance, on-time salary payment, bonus payments and good relationships with the supervisors can be evaluated as motivational factors in Turkey. Furthermore, hygiene factors, which are standard practices in developed countries, can be considered as motivational factors in developing countries like Turkey.
The following four critical factors that affect the productivity of technical personnel are inadequate supervision, inadequate communication, disrespectful treatment (mobbing) and salary and benefits, respectively. On the other hand, personnel's gender, personnel's marital status, union rules and influences, parking facilities and personnel's age appear to be the least important factors, respectively.

When the average mean of the factors in each category is calculated, the most important factor group appeared to be management factors with a mean of 3.777. Management factors are followed by working conditions with a mean of 3.658. Next, human factors are calculated as the third category with a mean of 3.644 , which is very close to the mean of the second category. The fourth category that has the lowest mean value of 3.207 is the external factors category.

\subsubsection{Factor Analysis}

Factor analysis is a statistical technique that is used to determine the extent to which a group of measures share common variance. It can be considered as a "data reduction" method, for the application to remove a few primary factors from a large preliminary set of observed variables. Thereby, the researchers will be able to estimate the major extents underlying the observed dataset [41]. In this research, factor analysis is conducted in order to discover the relationships between the factors and to define them in fewer factors. As an outcome of factor analysis, two goals are expected to be achieved: (1) decreasing the number of factors that represents the dataset, and (2) creating new structures (or classifications) by considering the relationships between factors.

\subsubsection{Multi-causal Factors Affecting Productivity of Technical Personnel}

Sixty factors that affect productivity were identified for this research by literature review and face-to-face meetings. However, the "personnel gender" factor is excluded from 
Table 6 Relative importance index of all factors

\begin{tabular}{|c|c|c|c|c|}
\hline Category & Factor description & RII (\%) & Mean & Ranking \\
\hline Human factors & Personnel's motivation & 86.60 & 4.330 & 1 \\
\hline Management factors & Inadequate supervision & 85.75 & 4.288 & 2 \\
\hline Management factors & Inadequate communication & 84.50 & 4.225 & 3 \\
\hline Working conditions & Disrespectful treatment (mobbing) & 83.75 & 4.188 & 4 \\
\hline Management factors & Salary and benefits & 83.50 & 4.175 & 5 \\
\hline Human factors & Team spirit of the crew & 83.15 & 4.158 & 6 \\
\hline Human factors & Personnel's experience and skills & 82.80 & 4.140 & 7 \\
\hline Human factors & Personnel's attitude and morale & 82.35 & 4.118 & 8 \\
\hline Management factors & Lack of clear organization chart and SOW (Scope of Work) & 82.30 & 4.115 & 9 \\
\hline Working conditions & Excessive shift length & 82.15 & 4.108 & 10 \\
\hline Management factors & Delay in salary payment & 82.00 & 4.100 & 11 \\
\hline Working conditions & Unsafe working conditions & 82.00 & 4.100 & 12 \\
\hline Management factors & Lack of detailed planning & 81.40 & 4.070 & 13 \\
\hline Human factors & Personnel's boredom and fatigue & 81.15 & 4.058 & 14 \\
\hline Human factors & Personnel's job satisfaction & 81.00 & 4.050 & 15 \\
\hline Management factors & Non-availability of information & 80.20 & 4.010 & 16 \\
\hline Working conditions & Unpaid overtime & 80.15 & 4.008 & 17 \\
\hline Management factors & Lack of recognition program & 79.30 & 3.965 & 18 \\
\hline Human factors & Loyalty to job & 78.95 & 3.948 & 19 \\
\hline Management factors & Discontinuity in crew & 78.50 & 3.925 & 20 \\
\hline Management factors & Lack of cooperation between departments & 78.35 & 3.918 & 21 \\
\hline Management factors & Necessity to re-do work & 77.75 & 3.888 & 22 \\
\hline Management factors & Composition of the teams & 77.15 & 3.858 & 23 \\
\hline Management factors & Excessive workload & 76.55 & 3.828 & 24 \\
\hline Management factors & Incompetent personnel & 75.90 & 3.795 & 25 \\
\hline Management factors & Unrealistic schedule & 75.15 & 3.758 & 26 \\
\hline Management factors & Non-availability of equipment & 75.05 & 3.753 & 27 \\
\hline Working conditions & Transportation to work & 74.75 & 3.738 & 28 \\
\hline External factors & Accidents at site as a result of poor site safety program & 74.50 & 3.725 & 29 \\
\hline Human factors & Perception/misperception & 73.50 & 3.675 & 30 \\
\hline Management factors & Non-availability of materials/softwares & 73.05 & 3.653 & 31 \\
\hline Management factors & Interruption and disruption & 72.85 & 3.643 & 32 \\
\hline Management factors & End of Project Effect & 72.75 & 3.638 & 33 \\
\hline Management factors & Out-of-sequence work & 72.55 & 3.628 & 34 \\
\hline External factors & Owner's representative intervention & 72.45 & 3.623 & 35 \\
\hline Management factors & Failure to utilize personnel's skills & 72.35 & 3.618 & 36 \\
\hline Human factors & Personnel's learning curve & 72.30 & 3.615 & 37 \\
\hline Working conditions & Noise, dust and radiation & 72.30 & 3.615 & 38 \\
\hline Human factors & Personnel's absenteeism & 72.00 & 3.600 & 39 \\
\hline Human factors & Loyalty to company & 71.40 & 3.570 & 40 \\
\hline Working conditions & Ventilation system (heating $\&$ air conditioning) & 70.55 & 3.528 & 41 \\
\hline Working conditions & Cleanliness of working space & 68.85 & 3.443 & 42 \\
\hline External factors & Demand of over-quality work & 68.75 & 3.438 & 43 \\
\hline Management factors & Lack of procedures & 68.15 & 3.408 & 44 \\
\hline Working conditions & Overcrowded work areas & 68.15 & 3.408 & 45 \\
\hline Management factors & Lack of personnel training and education & 68.05 & 3.403 & 46 \\
\hline External factors & Changes in drawings and specifications & 67.15 & 3.358 & 47 \\
\hline External factors & Method of construction & 65.65 & 3.283 & 48 \\
\hline External factors & Changes in contract & 64.80 & 3.240 & 49 \\
\hline Human factors & Personnel's physical limitations & 62.90 & 3.145 & 50 \\
\hline
\end{tabular}


Table 6 (continued)

\begin{tabular}{|c|c|c|c|c|}
\hline Category & Factor description & RII (\%) & Mean & Ranking \\
\hline External factors & Nature of project (size and complexity) & 60.80 & 3.040 & 51 \\
\hline External factors & Weather conditions/climate & 60.30 & 3.015 & 52 \\
\hline External factors & Congested construction area & 59.90 & 2.995 & 53 \\
\hline Management factors & Proportion of work subcontracted & 58.65 & 2.933 & 54 \\
\hline Management factors & Lack of workload & 56.75 & 2.838 & 55 \\
\hline Human factors & Personnel's age & 50.55 & 2.528 & 56 \\
\hline Working conditions & Parking facilities & 48.95 & 2.448 & 57 \\
\hline External factors & Union rules and influences & 47.05 & 2.353 & 58 \\
\hline Human factors & Personnel's marital status & 41.70 & 2.085 & 59 \\
\hline Human factors & Personnel's gender & 37.40 & 1.870 & 60 \\
\hline
\end{tabular}

factor analysis, because corrected item-total correlation value for this factor is 0.027 as explained in the Cronbach's alpha in Sect. 3.2. Using 59 productivity factors, the factor analysis was conducted. After the first run, the rotated component matrix was examined and as a result of the first analysis the 59 factors can be represented by 13 components.

After evaluating the results, 14 factors were excluded from the analyses. Ten out of 14 were removed due to having absolute value less than 0.45 which are; inadequate supervision, lack of clear organization chart and scope of work, lack of detailed planning, proportion of work subcontracted, failure to utilize personnel's skills, delay in salary payment, disrespectful treatment (mobbing), personnel's absenteeism, personnel's learning curve and incompetent personnel. The other 3 factors out of 14 which were representing only themselves after the first run of factor analyses, were also removed. These factors are "personnel's boredom and fatigue," "personnel's physical limitations," "accidents at site as a result of poor site safety program." In the second run, 45 factors were analyzed and as a result of this analysis 9 components were observed to represent 45 factors. Due to having an absolute value less than 0.45 , "Personnel's job satisfaction" factor was also removed from the analysis.

After the third and final run, the KMO and Bartlett's test measure of sampling adequacy were used to examine the appropriateness of factor analysis. The KMO score was 0.911 (greater than 0.5) which proves that the factor analysis is valid. Also, the approximate of Chi-square score was $8,142.342$ with 946 degrees of freedom, which is significant at 0.05 level of significance. According to these results, the factor analysis at the third run is considered as an appropriate technique for further analysis of the dataset. As a result of the third run of the factors analysis, only 9 main factors are extracted with the combination of the relevant variables, which will explain the $60.32 \%$ of the total variance. According to Hair et al. (2010), the minimum level of total variance explained should be $60 \%$ [42]. In this regard, it can be stated that conducted factor analysis is acceptable.

\subsubsection{Cluster Analysis}

Furthermore, in this study, cluster analysis was conducted on the dataset. The aim of the cluster analysis is to ascertain whether the factors are forming meaningful groups with regard to the socio-demographic questions asked in the questionnaire survey. After factor analysis, one of the conventional partitioning methods, the K-means method, is applied for all 60 factors by means of SPSS. However, the utilization of cluster analysis and its results fall short of explaining any significant relationships between individual characteristics and the productivity of the technical staff in the industry. Detailed results were given in Findings section.

\section{Findings}

As a result of the factor analysis, it was identified that the dataset could be expressed by 9 main factors. The results of factor analysis can be shown in Table 7 .

\subsection{Main Factor 1}

The first main factor has $28.23 \%$ of the total variances of productivity factors. This factor represents 8 components (or sub-factors) which are the "unrealistic schedule," "lack of procedures," "lack of cooperation between departments," "interruption and disruption," "discontinuity in crew," "outof-sequence work," "necessity to re-do work" and "inadequate communication." Due to covering all sub-factors that are directly related to management decisions and behavior, this category is called "Management Factors." Since this factor represents almost half of the total explained variances, it is considered the most important factor. Unsurprisingly, various researchers have studied the managerial aspects of construction projects in order to improve productivity. Even Ranasinghe et al. suggested a construction productivity improvement officer (CPIO) who should represent the 


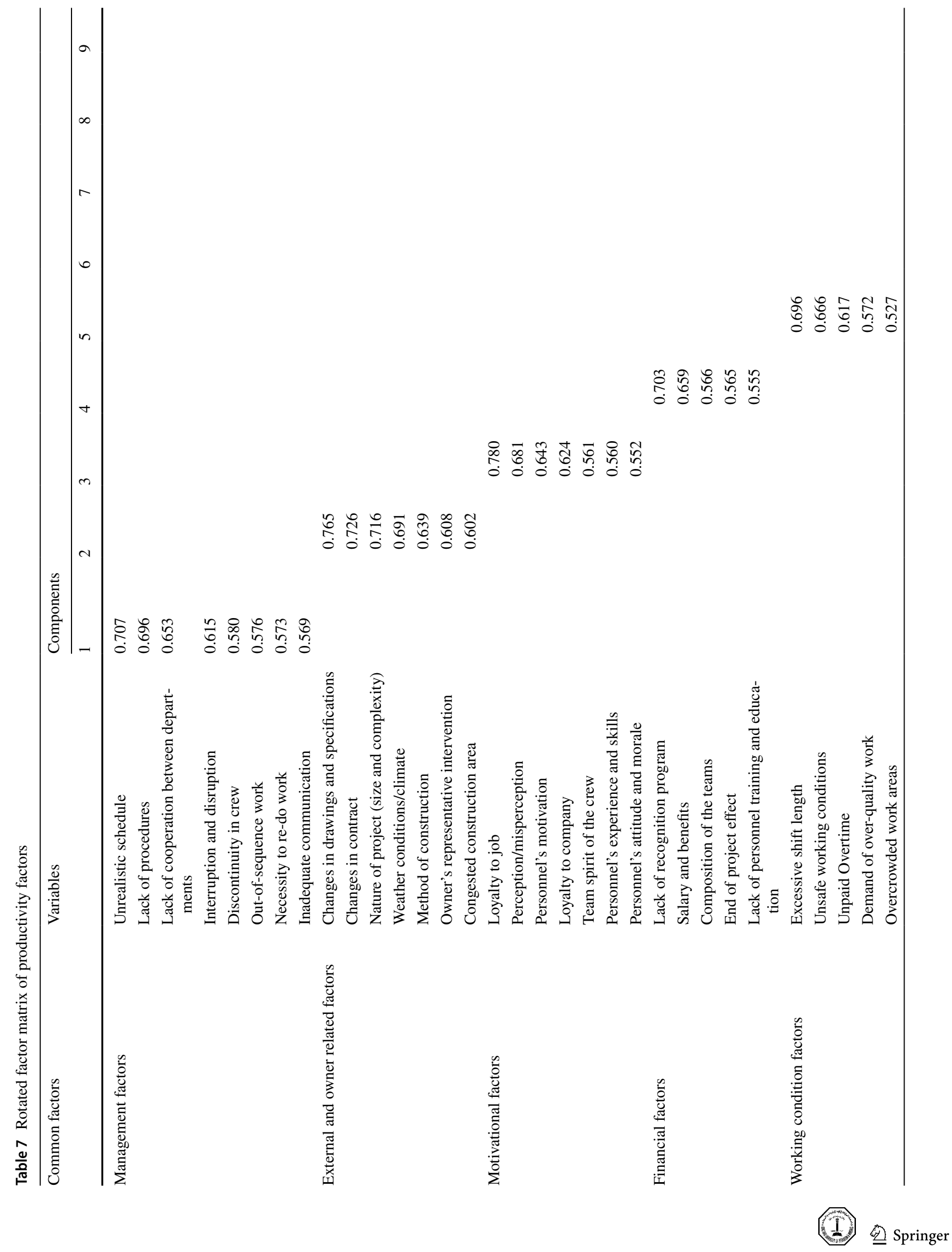




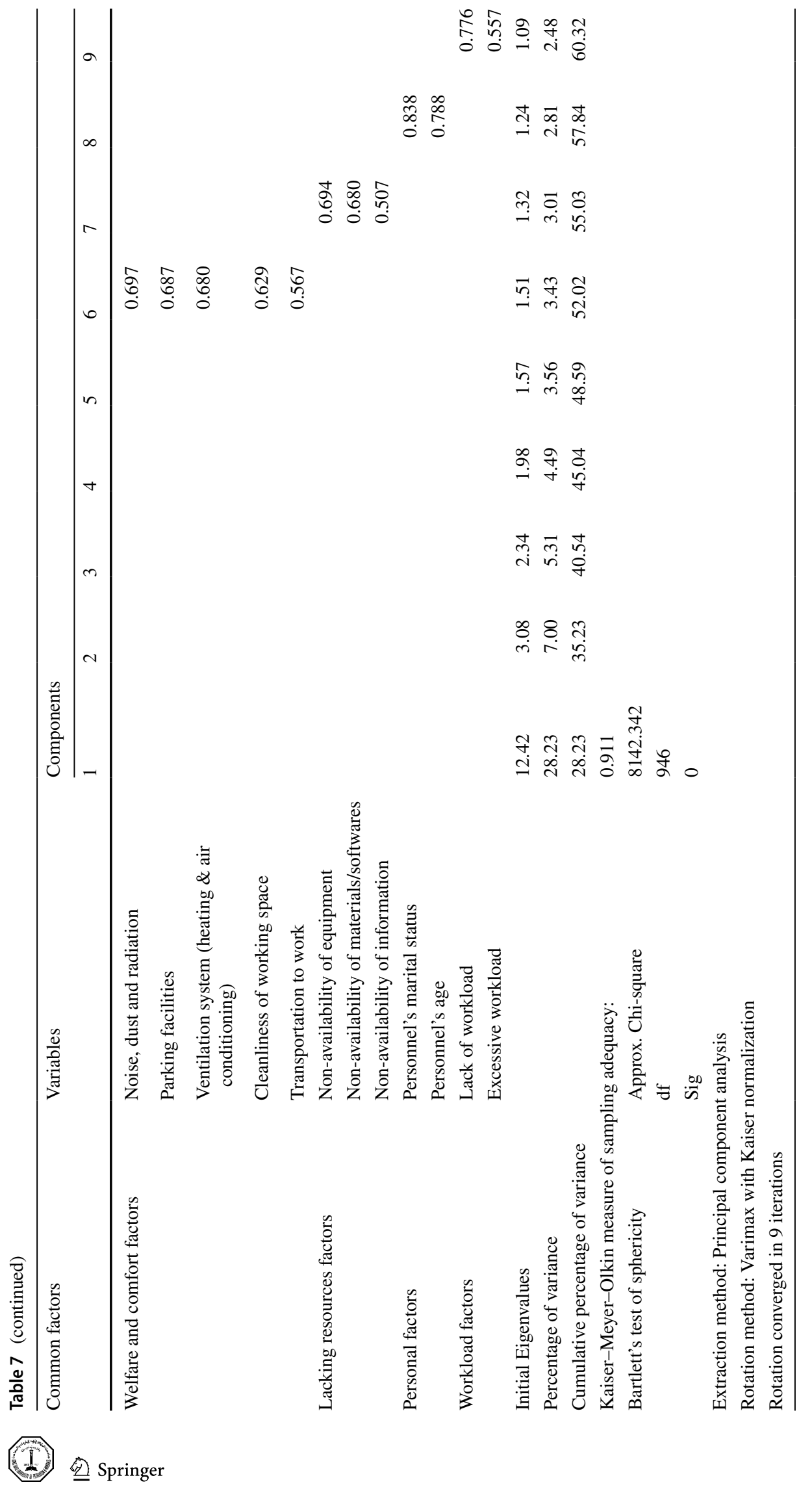


general contractor in the construction management organization and follow-up on all the works related to the productivity of the project [19]. "Unrealistic schedule" is the most important sub-factor that affects technical personnel productivity in management factors. "Lack of procedures" and "lack of cooperation between departments" are interrelated with each other and are directly linked to the management style. From the management perspective, the remaining 5 sub-factors in the management factor category should also be taken into consideration in order to increase technical personnels' productivity.

\subsection{Main Factor 2}

This main factor includes $7 \%$ of the total variance of the explained productivity factors. There are 7 sub-factors in this category, which are, namely: "changes in drawings and specifications," "changes in contract," "nature of project (size and complexity)," "weather conditions/climate," "method of construction," "owner's representative intervention" and "congested construction area." Since these sub-factors are specific to the project and cannot be controlled by the management, it is called "External and Owner Related Factors." From the employer perspective, "changes in drawings and specifications" might cause de-motivational acts and reduce productivity. It will also trigger most of the other mentioned productivity factors such as "necessity to re-do work," "the time affect," and "interruption and disruption". The same trigger effect can also be considered for the "changes in contract" sub-factor. In order to prevent a loss of productivity caused by "weather conditions/climate," necessary precautions should be implemented by foreseeing the effects from past experiences. For instance, in accordance with the location of the project, "weather conditions/climate" will affect the technical personnel, so in order to minimize this effect for the site team, necessary shading and heating/cooling facilities should be supplied. However, for the "owner's representative intervention," there is no preventive action, since its involvement could not be predicted before it occurs.

\subsection{Main Factor 3}

The third main factor covers $5.31 \%$ of the total variance. There are 7 sub-factors that form the third factor, which are "loyalty to job," "perception/misperception," "personnel's motivation," "loyalty to company," "team spirit of the crew," "personnel's experience and skills," "personnel's attitude and morale." Since all sub-factors are related to the motivation of employees, this factor is called "Motivational Factor." Since "loyalty to job" is an outcome of satisfaction with the job, employees' needs should not be neglected. Loyalty is also related to how the employees are treated. On the other hand, in order to prevent the effect of "perception/ misperception," direct communication is crucial. In a workplace, communication should be direct and open both upward and downward; otherwise, it damages relationships between workers and management team that might affect team spirit in a construction project. Remaining sub-factors are interrelated to each other; for instance, without motivated people, there will not be team spirit or loyalty to work or the company. Although "personnel's experience and skills" seems unrelated to the motivational factor, this sub-factor is one of 8 outcomes of loyalty to job sub-factors. If the companies could maintain their employees loyalty, that would bring experienced employees in the long term and decrease the risk of finding skilled workforce.

\subsection{Main Factor 4}

Main factor 4 accounts for $4.49 \%$ of the total variance explained. This factor consists of five sub-factors that are, namely: "lack of recognition program," "salary and benefits," "composition of teams," "end of project effect" and "lack of personnel training and education." Since all the sub-factors have a monetary effect, this factor is called the "Financial Factor." As it is understood from the result of factor analysis, although "salary and benefits" is a very important sub-factor for the financial factor, the "lack of recognition program" has a larger effect on productivity. "Composition of teams" seems to be more related to the management factor. However, according to the result of factor analysis it is a sub-factor of the fourth group. It can be explained as demonstrating that the salary of the team should be evenly distributed, because unfair salary distribution in a team will damage team spirit and will definitely affect productivity. Furthermore, the "end of project" effect is special to the construction industry. Since most of the technical personnel in the construction company works on project basis, "end of project" means starting the process of searching for a new job, a change of location and adaptation to a new project. Finally, the "lack of personnel training and education" sub-factor is not directly related to the financial factor; however, the training and education of an employee are costly. Some of the employers, especially in developing countries, are aware of these training and education costs.

\subsection{Main Factor 5}

The fifth main factor has $3.56 \%$ of the total variance explained. This factor has five sub-factors, namely: "excessive shift length," "unsafe working conditions," "unpaid overtime," "demand of over-quality work" and "overcrowded work areas." Since all the sub-factors are specific to work place, factor 5 is called "Working Condition Factor." "Excessive shift length" has the highest loading value (0.696) in the working condition factor. "Excessive shift length" might be 
tool for increasing total productivity on some occasions, but when it is persistent, fatigue will start. Thus, motivation of technical personnel will be affected negatively, and productivity will certainly fall. Secondly, the "unsafe working conditions" sub-factor affects productivity adversely. Especially in the Turkish construction industry, where 4 employees out of 100 are at risk of becoming a subject of a work-related incident as per the Turkish Statistical Institute (2013), this sub-factor is one of the weakest points of the industry [43]. Although "unpaid overtime" seems like a financial factor, since it changes from company to company it is also related to workplace characteristics. In a legal frame, it is not allowed to not pay for overtime work; however, most of the companies are not paying for overtime, especially for technical personnel in the construction industry. "Demand of over-quality work" might be related to many variables such as project specifications, owner intervention or managers' expectation. In any case, if the required quality of work is not in line with international standards, it might result in a learning curve and decrease productivity. "Overcrowded work areas" also have a negative effect on productivity of technical personals.

\subsection{Main Factor 6}

The sixth main factor explains $3.43 \%$ of the total variance. The five sub-factors of the sixth group are "noise, dust and radiation," "parking facilities," "ventilation system," "cleanliness of working space" and "transportation to work." All sub-factors are related to the working comfort of technical personnel; therefore, this factor is called the "Welfare and Comfort Factor." The "noise, dust and radiation" sub-factor has the highest loading (0.697) in factor 6. This sub-factor is mostly related to the working environment and the welfare of the employee. Thus, it is very important for both the health and the concentration of employees. The remaining sub-factors are related to comfort of the employee on the construction site.

\subsection{Main Factor 7}

The seventh main factor covers $3.01 \%$ of the total explained variance. It has three sub-factors: "non-availability of equipment," "non-availability of materials/software" and "nonavailability of information." All of the sub-factors are related with the availability of resources, accordingly this factor is called the "Lacking Resources Factors." It is obvious that productivity of technical personnel is directly related to resources, without proper software or equipment the productivity will definitely be reduced. This factor also has an effect on employees' morale and motivation. If employees are held back while doing their job with dedication due to lack of resources, they might lose their passion for that work.

\subsection{Main Factor 8}

The eighth main factor accounts for $2.81 \%$ of the total variance explained. The two sub-factors under this factor are "personnel's marital status" and "personnel's age." Since these two factors are the personal specification of the employee, this factor is called "Personal Factor." Even "personnel's marital status" seems not directly related to the productivity according to a study held by US Navy officers; married males achieve higher performance than single officers [44].

\subsection{Main Factor 9}

Lastly, the ninth main factor covers $2.48 \%$ of the total variance explained. The sub-factors under this factor are "lack of workload" and "excessive workload." Due to having two sub-factors related to workload this factor is called the "Workload Factor." It is also worth mentioning that there is no correspondence between the importance of items ranked by the respondents and the results from factor analyses. While factor analyses reveal the grouping of items that come together and make sense statistically, respondents' ranking of the importance of items reflects their priority for these items. Hence, the results of factor analyses and importance ranking should be evaluated separately by the authors. Rankings cannot give the relationships between motivational factors that are calculated with the aid of the relative importance index; the relationships between different demands are important to implement managerial policies in a construction company and Factor Analysis provides such information.

\subsection{Cluster Analysis}

After applying the cluster analysis to dataset, it is understood that the productivity of technical personnel in the Turkish construction industry cannot be classified by individual characteristics such as marital status, gender, age, experience, education and so on. For instance, for marital status, cluster analysis gave two clusters those have 307 members with 160 married, 147 single and members with 50 married and 43 single status. Similarly, analysis focused on gender gave two clusters those have 307 members (cluster 1) with 238 male, 69 female and 93 members (cluster 2) with 80 male and 13 female respondents. Clustering according to the level of education for three status (bachelor, master, $\mathrm{PhD}$ ) did not give any concrete result that any of clusters represents respondents' level of education (due to random distribution into the clusters). Furthermore, the experience of the respondents was also asked in the questionnaire survey by asking the number of years in the construction industry. In accordance with the predetermined 8 groups $(1-5,6-10,11-15,16-20$, 
26-30, 31-35 and $>35$ years experience), cluster analysis conducted with 8 clusters but results fell short to explain any correlation and clusters could not represent any experience level; in other words, respondents did not accumulated in any cluster according to their experience. On the other hand, "the environment" (conditions of the workplace, attitudes toward employees, etc.) that surrounds the "individual" (i.e., technical personnel) does influence productivity. "The environment," of course, is formed and structured by management. The effect of those factors is analyzed and discussed in the next section that focuses on the results of factor analysis.

\section{Discussion}

\subsection{Summary of Main Findings}

The 60 factors studied regarding the productivity of construction technical personnel in Turkey, were determined, discussed, compared with previous literature outcomes and are grouped under four major categories as follows: 15, in the human factors category; 25, in the management factors category; 10 , in the external factors' category; and 10, in the working condition factors category. According to the answers of the 400 respondents, the RII indicated that the five most important factors affecting productivity are "personnel's motivation," "inadequate supervision," "inadequate communication," "disrespectful treatment (mobbing)" and "salary and benefits." On the other hand, as per the RII's ranking of 59 factors, the five least important factors are: "personnel's gender," "personnel's marital status," "union rules and influences," "parking facilities" and "personnel's age" for the construction industry. Furthermore, the means of the four pre-defined factor groups, which are human factors, management factors, external factors and working conditions factors, were also calculated. Hereunder, most important factor group was identified as management factors, which are followed by working conditions factors, human factors and external factors, respectively.

At the later stage, factor analysis was conducted on the results of a questionnaire survey. All reliability scores of the factor analysis fall into the highest possible categories. Except for "personnel gender," which had a very low corrected item correlation value, all 59 factors were subjected to factor analysis. Factor analysis was performed three times and 15 factors were excluded through the analysis as explained above. As a result of the factor analysis, it was identified that more than $60 \%$ of the dataset could be expressed by 9 main factors: (1) management factors, (2) external and owner related factors, (3) motivational factors, (4) financial factors, (5) working condition factors, (6) welfare and comfort factors, (7) lacking resources factors, (8) personal factors, and (9) workload factors. For instance, excessive shift length, unsafe working conditions, unpaid overtime, demand for over-quality work and overcrowded work areas are grouped under factor 5 (working condition factors), according to the result of factor analysis. Based on the conducted factor analysis, statistically $60.32 \%$ of the 59 factors could be represented by the nine identified main factors. When the nine identified main factors were listed, the management factor represents $28.23 \%$ of all factors, which is also equal to $47 \%$ of the total variance explained.

It is worth mentioning that, factor analysis points out the factors which characterize construction industry as well. For instance, under Factor 1 "unrealistic schedule," "lack of procedures," "lack of cooperation between departments," "interruption and disruption," "discontinuity in crew," "outof-sequence work" seem to be a brief description of the construction industry that lack of construction management practices. On the other hand, the factors under Factor 2; "changes in drawings and specifications," "changes in contract," "nature of project (size and complexity)," "weather conditions/climate," "method of construction," "owner's representative intervention" and "congested construction area" changes in drawings and specifications," "changes in contract," "nature of project (size and complexity)," "weather conditions/climate," "method of construction," "owner's representative intervention" and "congested construction area" seem to be a brief description of the construction industry which is project based instead of process and where the contingent forms of contracting exist.

The other considerable finding of the study is the correlation between the RII means of management factors group and the results of factor analysis. According to the RII means of factors under each four pre-defined categories, the management factors group was identified as the category with the highest mean, which is in correlation with the results of factors analysis. It can be said that the management factors explain most of the factors that affect the productivity of technical personnel in the construction industry in Turkey. "Unrealistic schedule," "lack of procedures," "lack of cooperation between departments," "interruption and disruption," "discontinuity in crew," "out-of-sequence work," "necessity to re-do work" and "inadequate communication" are the most important topics that a managerial team should consider and improve in a construction firm. Results underlines the importance of management practices in the construction companies and construction management activities throughout any construction project that will direct effects on productivity of technical staff.

\subsection{Strength and Limitations}

Technical personnel's awareness of construction productivity has been unnoticed by academics and construction managers for a long time. Understanding their opinions, 
identifying the main factors and focusing on the most important factors that influence productivity can help technical personnel to increase their project performance and give them high motivation for their work. Therefore, the research has been conducted to identify and rank the factors affecting the productivity of technical personnel in the construction industry. According to the study, the management factor covers $47 \%$ of the factors which were statistically put in to factor analysis. In the light of the findings above, in order to improve technical personnel's productivity, industry professionals shall emphasize management factors. On the other hand, the research indicates that "the environment" (i.e., conditions of the workplace, attitudes toward employees and other factors) that surrounds technical personnel has influence on productivity, and this finding will shed light on managers who seek to increase job productivity and help them deal with hard working schedules. Since the construction industry is project based, and time limitations (i.e., project duration) are one of the most important parameters, certain alterations and arrangements may be made by top and mid-level managers to change the "working environment" (not only physical but also behavioral or managerial) for productivity. Although this research provides significant findings on factors of technical personnel productivity in the construction industry, a few limitations exist. First, there was only one criterion for the respondents, which was working in the construction industry. Asking more experienced technical personnel for their perception of productivity may reduce errors and give more solid results. Second, this research was conducted in Turkey, and the target population of this questionnaire was Turkish technical personnel. Thus, the study may seem like a local study; however, Turkish construction firms are active in an extensive geography all over the world.

\section{Conclusions}

As a conclusion of all analysis, the most important factors that affect the productivity of technical personnel have been identified as underlying management factors. It is recommended that the construction industry focuses on training future managers that will have a direct impact on the factors affecting productivity. Additionally, the results could not provide any information about individual factors influencing productivity and this finding is also important to change the focus from the "individual" to the "environment." However, "commitment of the company owners" will have a role in this process as well. The owners or upper management of the companies should delegate the financial power to the project manager in parallel with the responsibility they delegate. Otherwise, even if the managers are able to identify the factors affecting the productivity of their technical personnel, they might not have enough financial ability to eliminate or minimize these factors. It is believed that well-trained managers with the financial power to modify the identified managerial factors will improve the productivity of technical personnel in the construction industry, especially in developing countries like Turkey. Further research about the productivity of technical personnel may be conducted in a case study regarding the findings of the study and it is important to get feedback from site managers to make necessary updates in order to increase technical personnel's productivity.

Acknowledgements The authors express their thanks to all survey respondents. The authors would like to acknowledge the support of industry professionals who helped to determine the productivity factors at the beginning of the research. Also, we would like to acknowledge the Sustainable Building Design Lab, ULg for the survey development and their valuable support during the experiments and the analysis of data.

Availability of Data and Material Some data generated or used during the study are proprietary or confidential in nature and may only be provided with restrictions (i.e., anonymized survey data).

\section{Declarations}

Conflict of interest The authors declare that they have no conflict of interest.

\section{References}

1. Enshassi, A.; Mohamed, S.; Mustafa, Z.A.; Mayer, P.E.: Factors affecting labour productivity in building projects in the Gaza Strip. J. Civ. Eng. Manag. 13(4), 245-254 (2007)

2. Vogl, B.; Abdel-Wahab, M.: Measuring the construction industry's productivity performance: critique of international productivity comparisons at industry level. J. Constr. Eng. Manag. 141(4), 04014085 (2014)

3. Deloitte: 2018 Global Construction Industry Overview. https:// www2.deloitte.com/us/en/pages/energy-and-resources/articles/ global-construction-industry-overview.html (2018)

4. Turkish Contractors Association: Insaat Sektoru Analizi, Zor Bir Yil Olacak. http://www.tmb.org.tr/arastirma_yayinlar/tmb bulten_ocak2016.pdf (in Turkish) (2016). Accessed 15 May 2017

5. Sonmez, M.; Umit Dikmen, S.; Akbiyikli, R.: Time-cost relationships for superstructure projects in Turkey. Teknik Dergi 31(2), 9869-9896 (2020)

6. Ahbab, C.; Daneshvar, S.; Celik, T.: Cost and time management efficiency assessment for large road projects using data envelopment analysis. Teknik Dergi 30(2), 8937-8959 (2019)

7. Baradan, S.; Akboğa, Ö.; Çetinkaya, U.; Usmen, M.A.: Ege Bölgesindeki İnşaat İş Kazalarının Sıklık ve Çapraz Tablolama Analizleri. Teknik Dergi 27(1), 7345-7370 (2016)

8. Jarkas, A.M.; Bitar, C.G.: Factors affecting construction labor productivity in Kuwait. J. Constr. Eng. Manag. 138(7), 811-820 (2011)

9. Jergeas, G.F.; McTague, R.: Construction productivity: an auditing and measuring tool. AACE Int. Trans. CS91, 1-9 (2002)

10. BLS: Bureau of Labour Statistics. http://www.bls.gov/opub/hom/ inp/pdf/inp.pdf (2017). Accessed 25 May 2021 
11. Arditi, D.; Mochtar, K.: Trends in productivity improvement in the US construction industry. Constr. Manag. Econ. 18(1), 15-27 (2000)

12. Horner, R.M.W.; Talhouni, B.T.; Thomas, H.R.: Preliminary results of major labour productivity monitoring programme. In: Proc. of the 3rd Yugoslavian Symp. on Construction Management, Cavtat, pp. 18-28 (1989)

13. Allmon, E.; Hass, C.T.; Borcherding, J.D.; Goodrum, P.M.: U.S. construction labor productivity trends, 1970-1998. J. Constr. Eng. Manag. 126(2), 97-104 (2000)

14. Durdyev, S.; Ismail, S.; Kandymov, N.: Structural equation model of the factors affecting construction labor productivity. J. Constr. Eng. Manag. 144(4), 04018007 (2018)

15. Lema, N.M.: Construction of Labour Productivity Modeling. University of Dar Elsalaam, Dar es Salaam (1995)

16. Olomolaiye, P.; Jayawardane, A.; Harris, F.: Construction Productivity Management. Chartered Institute of Building, Bracknell (1998)

17. Thomas, H.R.: Construction baseline productivity: theory and practice. J. Constr. Manag. Eng., ASCE 125(5), 295-303 (1999)

18. Srinavin, K.; Mohamed, S.: Thermal environment and construction workers' productivity: some evidence from Thailand. Build. Environ. 38(2), 339-345 (2003)

19. Ranasinghe, U.; Ruwanpura, J.; Liu, X.: Streamlining the construction productivity improvement process with the proposed role of a construction productivity improvement officer. J. Constr. Eng. Manag. 138(6), 697-706 (2012)

20. Nasirzadeh, F.; Nojedehi, P.: Dynamic modeling of labor productivity in construction projects. Int. J. Proj. Manag. 31(6), 903-911 (2013)

21. Ulubeyli, S.; Kazaz, A.; Er, B.: Planning engineers' estimates on labor productivity: theory and practice. Proc. Soc. Behav. Sci. 119, 12-19 (2014)

22. Nguyen, L.D.; Nguyen, T.K.; Tran, D.Q.; Villiers, C.: Productivity in daytime and nighttime construction of urban sewer systems. J. Constr. Eng. Manag. 140(7), 04014021 (2014)

23. Li, X.; Chow, K.H.; Zhu, Y.; Lin, Y.: Evaluating the impacts of high-temperature outdoor working environments on construction labor productivity in China: a case study of rebar workers. Build. Environ. 95, 42-52 (2016)

24. Dai, J.; Goodrum, P.M.; Maloney, W.F.; Srinivasan, C.: Latent structures of the factors affecting construction labor productivity. J. Constr. Eng. Manag. 135(5), 397-406 (2009)

25. Kisi, K.P.; Mani, N.; Rojas, E.M.; Foster, E.T.: Optimal productivity in labor-intensive construction operations: pilot study. J. Constr. Eng. Manag. 143(3), 04016107 (2016)

26. Kaming, P.F.; Olomolaiye, P.O.; Holt, G.D.; Harris, F.C.: Factors influencing craftsmen's productivity in Indonesia. Int. J. Proj. Manag. 15(1), 21-30 (1997)
27. Lim, E.C.; Alum, J.: Construction productivity: issues encountered by contractors in Singapore. Int. J. Proj. Manag. 13(1), 51-58 (1995)

28. Thomas, H.; Maloney, W.; Horner, R.; Smith, G.; Handa, V.; Sanders, S.: Modeling construction labour productivity. J. Constr. Eng. Manag. (1990). https://doi.org/10.1061/(ASCE)07339364(1990)116:4(705)

29. Heale, D.G.: Qualitative and Quantitative Analyses of Factors Affecting Productivity in Canadian Construction Projects (Doctoral dissertation, Memorial University of Newfoundland) (1993)

30. Kazaz, A.; Manisali, E.; Ulubeyli, S.: Effect of basic motivational factors on construction workforce productivity in Turkey. J. Civ. Eng. Manag. 14(2), 95-106 (2008)

31. Liberda, M.; Ruwanpura, J.; Jergeas, G.: Construction productivity improvement: a study of human, management and external issues. In: Construction Research Congress: Wind of Change: Integration and Innovation, pp. 1-8 (2003)

32. Mahamid, I.: Contractors perspective toward factors affecting labor productivity in building construction. Eng. Constr. Archit. Manag. 20(5), 446-460 (2013)

33. Dai, J.; Goodrum, P.M.; Maloney, W.F.: Construction craft workers' perceptions of the factors affecting their productivity. J. Constr. Eng. Manag. 135(3), 217-226 (2009)

34. IBM SPSS Software: https://www.ibm.com/analytics/spss-stati stics-software (2020)

35. Weisberg, H.F.: The Total Survey Error Approach. The University of Chicago Press Ltd, Chicago (2005)

36. Robbins, S.P.; Judge, T.A.: Organizational Behavior Prentice Hall. Prentice Hall, Hoboken (2003)

37. Rowold, J.; Heinitz, K.: Transformational and charismatic leadership: Assessing the convergent, divergent and criterion validity of the MLQ and the CKS. Leadersh. Q 18(2), 121-133 (2007)

38. Abdulkadir, M.R.; Lee, W.P.; Jaafar, M.S.; Sapuan, S.M.; Ali, A.A.A.: Factors affecting construction labour productivity for Malaysian residential projects. Struct. Surv. 23(1), 42-54 (2005)

39. Brent, R.P.: Algorithms for Minimization Without Derivatives. Courier Corporation, Chelmsford (2013)

40. Findikci, I.: Insan kaynaklari yonetimi. Alfa Yayinleri, Istanbul (2000)

41. Everitt, B.S.; Dunn, G.: Applied Multivariate Data Analysis, Vol. 2. Arnold, London (2001)

42. Hair, J.F.; Black, W.C.; Babin, B.J.; Anderson, R.E.: Multivariate Data Analysis. Prentice Hall, Hoboken (2010)

43. Turkish Statistical Institute: Occupational Health and Safety Research Report. https://tuikweb.tuik.gov.tr/PreHaberBultenleri. do? id=16118 (2013)

44. Ryu, M.K.S.: An Analysis of the Relationship Between Marital Status and Family Structure and On-The-Job Productivity. Naval Postgraduate School, Monterey (2002) 